\title{
Participative and Decolonial Approaches in Environmental History
}

\author{
Sofía De la Rosa Solano , Alex Franklin, and Luke Owen
}

\section{Introduction}

Environmental history is at the forefront of transdisciplinary methodological innovation. Understood as the field in charge of researching the mutual relationships between humans and non-humans through time,

Some of the literary quotations included in this chapter have been translated from Spanish to English by the first author.

S. De la Rosa Solano $(\varangle)$

Groningen University, Groningen, The Netherlands

e-mail: s.de.la.rosa.solano@rug.nl
A. Franklin · L. Owen
Centre for Agroecology, Water and Resilience (CAWR), Coventry University, Coventry, UK
e-mail: alex.franklin@coventry.ac.uk

\section{Owen \\ e-mail: ab2943@coventry.ac.uk}


environmental historians argue that a broad set of skills and methodologies can be used for this type of research. ${ }^{1}$ Indeed, some authors use carbon data, pest analysis, animal biology or Geographical Information Systems (GIS) to enrich narratives about the past that had previously been based mainly on written archival sources. Most of these methods aim to include biological and physical data about non-humans. In parallel, methods from social sciences and other humanities have also been included in environmental history research, such as discourse analysis, landscape reconstructions based on artistic representations, or participative methods. The inclusion of qualitative methods aims at better understanding the notions and imaginaries that determine society's relationships with non-humans. ${ }^{2}$

Focusing on social research methods, this chapter seeks to explore the relationship and use of decolonial participative approaches in environmental history. By doing so, we aim to contribute to the discussion on the methodological challenge of doing environmental history. Through four sections, a three-element proposal is outlined involving: first, the need to use methods from social sciences to recollect historic data through interacting with people and places. Second, to challenge the notions of legitimacy inherited from historic research methods, by validating people's knowledge as fundamental sources in the construction of environmental history narratives. And third, to think of environmental history research as an exercise that can be infused with transformative power for environmental justice. The main argument is that decolonial and participative methods are useful tools to build environmental histories that are more inclusive and communicate better with today's society. We also argue that using participative and decolonial approaches contribute to environmental awareness and political action, making environmental history a powerful discipline in contributing to a decolonial

\footnotetext{
1 This definition of environmental history is based on McNeill (2003).

${ }^{2}$ To illustrate this point, one example can be found in river histories. One environmental history that is based on bio-physical data and methods can be found in Kraikovski and Lajus (2017). On the other hand, authors such as Vladimir Sánchez have used press analysis as sources to understand the evolution of society-river relationships (Sánchez-Calderón, 2017).
} 
environmental justice. ${ }^{3}$ This is in no way a proposal to dispose of other ways of researching environmental history. This suggestion also acknowledges that there are limitations to what participative and decolonial methods can contribute to environmental history and to environmental justice movements more broadly.

Even though there are many examples of environmental history studies with complex and multi-disciplinary methodologies, we argue there is still work to be done in building an inclusive and decolonial approach to this discipline. ${ }^{4}$ To understand what this approach would entail, in this chapter we mostly focus on literature from Latin America on historical research, participation and environmental history. As will be shown, in this region there has been a long-term influence of the decolonial turn, a long tradition of participative methods, and a strong and consolidated environmental history body of literature. For scholars outside of Latin America, this discussion becomes relevant as it deals with methodological approaches to overcome exclusionary and institutionalized narratives of the past. It enriches the dialogues between different traditions of historical research by translating the Latin American discussions into English. It also enters the debate in Anglophone literature of interpreting the themes and focus of the Latin American environmental historiography as tragic. According to Mark Carey, there is a prevalence in this region of a "pervasive declensionist narrative, which is to say, stories of imperialist extraction and environmental degradation except when conservationists could successfully prevent destruction" (Carey, 2009 , p. 222). The contribution of this chapter to this discussion will be made by contextualizing the construction of this declensionist narrative. Carey's warnings of the limitations of this approach are valid. However, the thinking behind this narrative can be useful to strengthen a scholarly tradition that builds critical and inclusive research, which engages with

\footnotetext{
${ }^{3}$ I adhere to the Álvarez and Coolsaet approach to environmental justice from a decolonial perspective. This proposal entails the acknowledgement of the colonial difference from a subaltern perspective. It is place-based and admits "capitalist destruction of nature as operating through heterogeneous mechanisms that are typically more brutal in places marked by colonialism and constructed as the periphery of the world-system" (Álvarez \& Coolsaet, 2020, p. 15).

${ }^{4}$ For a global state of the art in English of environmental history, see Hughes (2016).
} 
the larger discussions of equality. Lastly, this is an approach that hopes to bring attention to the communication of historical work to a larger audience, as "history can be characterized by its communicative nature, since it does not exist if it is not told" (Gallini et al., 2015, p. 9).

Since this chapter discusses the use of participative methods for environmental history, these are broadly defined as those involving people's knowledge for scientific research. They have a long trajectory in social sciences, while their use in humanities is increasing. The relevance of participative approaches for environmental history is that it helps historians to get involved with communities and landscapes that are not reachable through other methods. By involving researchers in the specific places they are researching, participative methods are producing situated knowledge. Situated knowledge has been broadly explored within decolonial studies as a way of overcoming Universalist assumptions that expand further inequalities. They are an integral part of the decolonial turn; a social, intellectual and cultural movement that aims to give a "new understanding of the global and local relations... as contestation of the Western eurocentric modernity, global capitalism and colonialism, which are an inseparable trilogy" (Curiel, 2014, p. 49).

The first section of this chapter reviews how historic research practiced inclusivity in general, since for historians, participative methods are less common than in other disciplines, such as anthropology and sociology. The second section discusses how participative research as a movement developed at the same time that historians were searching for more inclusive methods. In the third section, we illustrate how the characteristics of participative approaches, such as inclusivity and critical thinking, can be used for environmental history through the concept of memory. Lastly, we offer some final concluding thoughts.

\section{"To Include" in Historical Research}

This section explains how the discipline of history has worked the issue of inclusivity; this lays the ground for the subsequent use of participative approaches. This is important in thinking about participative methods for environmental history because it highlights the difficulties, inherited 
from the main historic discipline in hearing subaltern voices. It also sheds light on the specificities of the work of the historian; it therefore helps explain the ways and challenges of using people's knowledge to build legitimate narratives of the past.

It is first important to understand that historical research is tasked with examining the past while wearing the spectacles of the present, or that "writing history is an optimistic exercise towards the future motivated by concerns from the present" (Gallini et al., 2015, p. 12). As Eric Hobsbawm states, the past is "a permanent dimension of the human consciousness, an inevitable component of the institutions, values and other patterns of human society" (Hobsbawm, 2011, p. 54). Moreover, the discipline of history is the way in which society interprets the past and the realities and structures we inherit from it, from a scientific point of view. These interpretations, that are partial and only cover specific aspects of the past, are known as historiography, meaning, how history has been written. Charles Bergquist describes historiography as explanations of "how in the past observers and schools of thoughteach influenced by historical processes, national loyalties, ethnics and of class, and intellectual currents and cultural perspectives-interpreted a determined historic reality" (Bergquist, 1989, p. 212).

In broad terms, history understood as a scientific discipline comes from the discussions of the eighteenth and nineteenth centuries (mostly in Europe) that looked to legitimize the project of modernity, where absolute truths could be achieved through the scientific method. ${ }^{5}$ Those notions are challenged today, and history has long since moved from the pretensions of creating absolute narratives of the past. Nonetheless, most of the methods of history reflect the interests and discussions of the eighteenth and nineteenth centuries, and have retained the goal of finding reliable ways to understand the past. The consequence is that historic methods have focused on finding ways to guarantee that reliability. Furthermore, in broad terms, most historic research is done by following the material traces (known as sources) of the past in the present, in the form of archives, buildings, images, objects, landscapes

\footnotetext{
5 On the debates around these ideas, see Wallerstein (1994; Lander (2000).
} 
and others. Moreover, there is a strict process of challenging the legitimacy of the source and the information it provides, known as source criticism.

This process relies heavily on the availability of sources and the fact that the researcher deems the contents of these sources to be legitimate. Prioritizing written documents is based on a situated idea of scientific knowledge that corresponds to the interests of imperial powers, categorized in decolonial literature as the Global North. ${ }^{6}$ As such, the discipline of history in its origins responded to particular interests and focused on those aspects of what was available and deemed legitimate: mainly studies of aristocracy and political events. Soon, intellectuals noticed that this approach was exclusionary of large segments of the population, and that findable and legitimate sources only gave a particular type of information, since "different types of knowledge are expressed in different ways, which are doubtlessly difficult to decode" (Gallini et al., 2015, p. 21). Therefore, historians started looking for ways to be more inclusive in their analysis of the past.

This search started a long tradition of including popular voices in history, forming what historians like Ranahit Guha and Mauricio Archila have called the quest for "the voices silenced by History" (Archila Neira, 2005; Guha, 1982). Some authors trace this interest for more popular and less aristocratic voices within the disciplinary praxis of history to Marx (Burke, 1984). Another precedent is what in the eighteenth century was called popular history, when intellectuals were developing arguments in the construction of nation states (Burke, 1984). However, the most clear and recognized reference to include working classes in historic research is the work of Edward Palmer Thompson in "The making of the English working class" in 1963 (Thompson, 1963). In the late twentieth century more movements joined, such as the Annales in France, the British Cultural Marxism, the Indian subaltern studies and others. Together, they consolidated what came to be known as "history from below". This subsequently became an integral part of fields of history such as social history, cultural history, labour history and others.

\footnotetext{
${ }^{6}$ In opposition of the Global South, a category that contains the spaces of oppression or affectation by colonialism, imperialism and capitalism. On the Global South and Global North categories, see Fernandez et al. (2014).
} 
Practitioners of the history from below face the challenge of scarce availability of sources. This is because, unlike other approaches, the archives of the working classes are less preserved or less available than others. As Mauricio Archila points out, it is no coincidence that, in parallel with the growing interest in popular classes, oral history was also in a process of consolidation within history, as both "methodological appendix or epistemological alternative" (Archila Neira, 2005, p. 297). Oral history is a complex and rich approach to the studies of the past. It has been described by Alessandro Portelli as a work of relationships, mainly between past and present in "an effort to establish, through memory and narrative, what the past means to the present" (Portelli, 2009 , p. 21). As a legitimate data collection approach, it only gained acceptance from academic historians in the Global North after World War II (Archila Neira, 2005). Combined with methods from other disciplines such as anthropology and sociology, massive oral archives were created to analyse the horrors of the war that did not leave a paper trace, giving birth to many epistemological and methodological discussions on how to collect and analyse this data within the professional practice of history.

In the Global South, the high rates of analphabetic population and scarcity of written documentation made historical research particularly difficult. In the case of Latin American, bottom-up approaches were rapidly increasing in the second half of the twentieth century. This is because the scarcity of written sources was met with the strong influence of Marxist thinking within intellectuals, making oral testimonies a more appealing source for the understanding of the class struggle. With time, the oral testimony in history evolved from being a complement for written sources to being the core of an epistemological approach that aimed to hear the voices silenced by historiography. In this context, the oral traditions that already existed independently from academia "formed the memory in which historic methods were supported...becoming another source to get a better understanding of the past" (Archila Neira, 2005, p. 300). However, historians were not the only ones in Latin America who felt more willing to work with these sources for researching the past. On the contrary, sociologists and anthropologists were leading the discussion. The next section explores how participation has been 
constructed in the social sciences, in parallel to the discussions on its inclusion in history.

\section{Participation, Decoloniality and History}

There is not one unique way in which to incorporate public participation in research. Also, its use does not necessarily align with the decolonial turn; rather it depends on how, why and the extent to which it is used. For example, since the nineteenth-century anthropologists have used ethnography to understand the dynamics within communities, sometimes under a colonial gaze (Tax, 1992). In contrast, decolonial participative methods have a strong relationship to the methodological approach known as "action research". Because of this, it aims not only at understanding realities, but rather at transforming them. There are many versions of action research; it takes "many forms depending on the particular context and issues involved" (Kindon et al., 2007, p. 1), and the differences "can be political, practical and epistemological" (Kemmis et al., 2014, p. 4). For that reason, we limit my focus here to its development in Latin America, where the approach evolved hand-in-hand with decolonial thinking.

Action research was first mentioned as a methodology of the social sciences, to achieve changes in society, in a publication in 1946 by Kurt Lewin in the United States of America (Lewin, 1946). Lewin challenged the separation between the production and use of knowledge, and thought of ways in which that distance could be reduced. However, he worked with a focus on "social improvement" that, even though it seemed to consider knowledge production from communities themselves, was still largely based on authoritarian views of change towards specific forms of development. Based on this approach, action research flourished during the last century in Anglophone literature, hand-inhand with organizational science, aiming to improve problem solving and social engineering (Rahman \& Fals Borda, 1992).

By 1980 action research was already an established methodology; with multilingual literature written about it, it was being applied on all continents, including by various globally recognized organizations 
such as the Food and Agricultural Organization (FAO) and the United Nations Educational, Scientific and Cultural Organization (UNESCO) (Rahman \& Fals Borda, 1992). Since then, many other studies have been published, and its effectiveness and relevance have been widely discussed among academics and practitioners (Kemmis et al., 2014). Unlike the Anglophone context, in other parts of the world action research occurred and developed mainly outside academia, but that "occurrence" outside academia is part of its identity (Salazar, 1992). In Latin America, action research emerged as a critique of the separation between communities and researchers, a distance that seemed to prevent scientific work from actually improving the living conditions of those communities (Salazar, 1992).

A vivid debate among social science practitioners working in Latin America took place in the decades of 1960s-1980s, at the core of which was known as the "New Social Sciences" (Zamosc, 1992). These debates showed a critical attitude to imported models of analysis, since they were found to be too neoliberal and foreign for the Latin-American realities. These "New Social Sciences" were influenced by new approaches to Marxism, the pedagogy of the oppressed, and the liberation theology. Central to these was the assumption that deep engagement of the researcher was necessary if the goal of academic work is to achieve change in society (Salazar, 1992). One of the ways in which this movement developed was through direct work with communities. Moreover, it was critical with the notion of objectivity that was embedded in the Anglophone version of the participant observation method. Central in these debates were anthropologists and sociologists working with indigenous and peasant communities, looking to de-construct the colonial and imperial background of social sciences, particularly in the Global South (Tax, 1992). These were some of the debates that simultaneously nurtured the decolonial turn.

Scholars associated with the New Social Sciences also argued that science is usually seen as a non-human entity, objective and without interest (Tax, 1992). For them, science is intrinsically human, and therefore it responds to society's interests and structures. This critique goes particularly to the process of knowledge production, that generates an "elitization" of knowledge production. In response, they proposed 
a "democratization" of scientific work. This translated into including the communication of research as part of the research design itself (Rahman \& Fals Borda, 1992). By doing this, their goal was to change the nature of social research by creating Participatory Action Research (PAR). PAR is proposed as a method for not only working with the communities, but also having the communities designing and actively taking part in the research process.

In a reflective text on the evolution of PAR in Latin America, the sociologist Zamosc says that the objectives of researchers using PAR are empathetic and synergic. They seek to "obtain valid knowledge that corresponds to the interest of the researched groups and joins active and direct efforts to achieve these groups goals" (Zamosc, 1992, p. 98). Overall, the purpose and reach of the movements in Latin America using these approaches to the field was to create a social science for liberation, where the role of the researcher was to "help exploited groups to achieve their revolutionary historic mission" (Zamosc, 1992, p. 98). The main method of this militant research, as they called it, is participative observation. The largest of these initial exercises was carried out by the sociologist Orlando Fals Borda in the region of Córdoba (Colombia) in the 1970s. The main accomplishment of the project was to recover historic information on class struggles in the region through interviews and exploration of personal archives. This was known as a "critical recovery of history". The result was a compilation of the history of the class struggles of the peasants in the Córdoba region and the revitalization of those fights.

It is important to mention here that for Fals Borda, a true science of the people also includes the environment, as it contains "empiric or practical knowledges, from common sense, possessed by ancestral tradition in working classes. This knowledge allows them to create, work and understand with, mainly, the resources coming from nature" (Rahman \& Fals Borda, 1992, p. 213). Fals Borda subscribed to the view that a science of the people would, by itself, strengthen the claims from the working classes. A pivotal point for him was the socialization of the research findings, to give working classes the opportunity to achieve new levels of political consciousness. In short, for Fals Borda, research can only be 
designed with people from communities and their leaders, and with the goal of social transformation.

In the past three decades, the decolonial movement has elaborated on these and other postulates to strengthen a theoretic frame, however, that frame "does not reflect a problematization of the methodologies used in field" (Puentes, 2015, p. 2). It has been mainly the work of feminist scholars and activists to challenge this aspect and write literature on the topic. María Lugones proposes a theory of intersectionality to decolonize gender, based on the history of the groups that are being oppressed (Lugones, 2018). Ochy Curiel reflects in depth on how it is central that research on communities is led by people from those communities, by legitimizing their knowledge and problematizing the conditions of production of knowledge (Curiel, 2014). Julia Suárez-Krabbe reflects from an anthropological perspective about the necessity of using engaged research, as postulated by Fals Borda, to actively transform injustices (Suárez-Krabbe, 2011).

In specific relation to historical research, arguably the most important contribution is the work of the Bolivian sociologist Silvia Rivera Cusicanqui (De Souza Veras, 2012). In 1983 she co-created the Workshop for Andean Oral History (THOA, for its initials in Spanish), which still continues today in La Paz. Rivera is critical towards PAR as she finds it does not transform the instrumentalization of communities within the production of scientific knowledge. She also critiques the strong Marxist influences in PAR, since she considers it is a theory that does not translate to the Latin context, and it does not deal with the background differences between researcher and researched. As an alternative, through oral history in the Aymara language, the THOA aims to collect the "existence of diverse historic rationalities, with legitimizing functions" (De Souza Veras, 2012, p. 6) that went against traditional Bolivian historiography written in Spanish. With this methodology, she aims to shift the starting point of historic reflections from academia to the communities themselves within their own cosmologies and realities. THOA has been considered the main tool from which "to defend a history written from the bases with ethnic revindication where the protagonist of the history is the one to reconstruct its past" (Apaza, 2019, p. 6). THOA has also 
been recognized as a source of political-ideological resistance within the colonial context of Latin America (De Souza Veras, 2012).

Thus far, it has been explained how some researchers were keen on using participative methods for researching the past. However, not all historians agreed with these approaches. For example, as a response to Orlando Fals Borda's most important work, the "Historia Doble de la Costa" (Double history of the Colombian Caribbean Coast), the Latin-Americanist historian Charles Bergquist wrote a paper entitled "En Defensa de la Historia" (For the defence of history, Bergquist, 1989). In this paper, Bergquist criticized the use of PAR for historic research in depth, claiming inaccuracy, poor source criticism and neglection of the existing historiography on the topic of study. He claimed Fals Borda "constantly attempts to subvert the cause of science in the name of political engagement" (Bergquist, 1989, p. 226). Participative methods in general received further critiques, such as idealization of communities, as they are not equipped with tools to recognize the inner inequalities of gender or race within them (Salazar, 1992). While most of these critiques raised points for improvement in the use of participative methods for historic research, we subscribe to the argument that it is indeed necessary to subvert the cause of science. By subverting, we particularly refer to being critical of established methods, notions and theories that claim universal objectivity and accuracy. This applies especially when these approaches do not question the power mechanisms that are creating and reproducing social and environmental inequality.

In this and the previous sections, we have discussed how historians were looking for ways to be inclusive, and in parallel, how other social scientists in Latin America were questioning scientific methodology and epistemology as a whole in the quest for social equality. The discussions that gave room to the decolonial turn were going hand-in-hand with the development of a particular type of action research, different from its contemporary in Anglophone literature. The scholars at the centre of this debate were questioning not only the separation between researchers and communities, but also the nature of scientific knowledge itself. Action Research and Participative Action Research became useful tools in the quest to transform realities. During the last three decades these debates have changed form, questioning the matter of 
how the inequalities experienced nowadays are linked to the project of modernity and coloniality that is expressed in capitalism. Decolonial theory places emphasis on finding out the particular ways in which this system is oppressive; it questions relationships of power between centre and peripheries, the nature-social dichotomy, and the homogenization of people. In this process, research about the past has taken an important role, as it is regarded as an empowering tool for communities (Zamosc, 1992).

\section{Environmental History, Decoloniality and Participative Methods}

As with many other social disciplines and humanities, in the second half of the twentieth century, historians started asking how to expand historic narratives to include the non-human. The epistemological and practical consequences of the environmental turn in history have been widely researched by other authors (Hughes, 2016). Nonetheless, it is important to mention that environmental historians built a theoretical body to challenge the exclusion of the non-human in history, and a methodological praxis that reached into other sources, interpretations and disciplines to change our interpretation of the past. Some scholars have approached the task of including non-humans by focusing on their agency in history. Others have challenged established narratives on weather and culture, by reconstructing the past based on archival and biophysical information. In this way, many different disciplinary and methodological elements have been used to build the narrative of environmental history. A summary of how environmental historians have thought about methods can be found in Donald Hughes' book What is Environmental History?. He compiles the views of several English-speaking authors on the matter and highlights how environmental historians can collect data on societies, the biophysical world and ideas, establishing a dialogue with other disciplines and using the lens of the historic method. He concludes by saying "environmental history refuses to cut culture from nature. Equally it must not cut history from geography" (Hughes, 2016, p. 126). 
In terms of how environmental history from Latin America has been influenced by the decolonial and participative approach, there is some discussion; it has been acknowledged that in Latin America environmental history has its own characteristics and there is already a strong body of production that has particularities when compared with environmental histories from other latitudes (Sánchez-Calderón \& Blanc, 2019). Mark Carey coined the term "chronic deficiency" for the way Latin American history is typically told: that is, as a story of deterioration. According to Carey, this focus does not allow the seeing of other narratives or processes in the region that were part of the complex process of socio-environmental change. On the other hand, economic historian Patricia Clare of Costa Rica wrote in 2009 that there is an ideological difference between the Latin American environmental historiography and that from other places, making Latin American histories more politically engaged, especially in working towards the end of the deep inequalities of the region (Clare, 2009).

In 2019, the environmental historians Vladimir Sánchez and Jacob Blanc highlighted the close relationship between the environmental deterioration denounced in declencionist narratives, with the social inequalities in Latin America (Sánchez-Calderón \& Blanc, 2019). They point out that because of this close relationship, the environmental justice movement and environmental history in the region have grown hand-in-hand; however, they also mention other types of Latin environmental historiography that have been written since 2010, with fewer declensionist narratives. Stefania Gallini wrote two pieces analysing this same topic, one in 2009 and one in 2020 (Gallini, 2009, 2020). She reflects on how the particular context of inequalities and neoextractivist economies in Latin America has made environmental historians more interested in explaining the source of these realities than in other topics. She argues that environmental history in Latin America has focused more on dialoguing with environmental and development studies than with the discipline of history. She also points out that, unlike in other places, environmental history in Latin America is written with the goal of having an impact on policy and social transformation. 
In line with these arguments, we suggest that environmental history from Latin America is influenced by the development of the decolonial literature and can contribute to create narratives from the Global South. This is because it aims to support socio-environmental justice claims, challenges the preference of written sources over others, and has especial interest in the history of extractivist economies. Accordingly, within the claims of the environmental justice movement, the work of environmental historians should be able to recognize dynamics of exclusion, which are particularly acute in the Latin American case. This, in turn, is why inclusive methods for environmental history have been more popular in this part of the world. In short, this influence is visible starting with the selection of research topics that have a denunciation tone towards the quest for participative methodologies. It extends to theoretical approaches, use of concepts and the proximity it has with other disciplines like political ecology or development studies.

One great example of these developments is the publication, in 2015, of a manual on how to practice environmental history in Colombia by Gallini et al. (Gallini et al., 2015). The manual was part of a collection of volumes, published with the support of the Colombian government, to produce technical data and recommendations to guide the conservation of strategic ecosystems. The government wanted to create conservation areas, taking into account ecological data and considering the information from the communities that had inhabited the space. As pointed out by the authors of the manual, to be part of this process opened the way for environmental history towards activism and forced it out of the "dangerous ivory tower of academia" (Gallini et al., 2015, p. 7). The idea of the authors was to illustrate "the imperious need of believing in the transformative capacity of a historic research" (Gallini et al., 2015, p. 64), made ideally through co-creation with communities and being appropriated by locals and decision-making stakeholders. The manual warns about the importance of history, since not being aware of it diminishes the ability of adaptation for communities and governments. Another point in the manual refers to the power environmental history can play in granting access to natural resources to different stakeholders, emphasizing that researchers have the responsibility of offering the opportunity of knowledge to build a more equal society. The methodological proposal 
contained within the manual on how to make environmental history is openly participative, asking researchers to use in-depth interviews and collect archives from local inhabitants. Here, it is important to highlight that this publication came not only from one of the front figures in environmental history in Latin America, namely Stefania Gallini, but also that it was published by a governmental institution that had in mind to affect policy. The origin of the manual, speaks of how these are tools for transformation, not only for academia.

Another critical reflection on the work of including oral testimonies in doing environmental history in Latin America was written by Emilio Vargas Mena (Vargas Mena, 2014). His travels through the territory object of study, had the goal of "trying to read the printed prints that human experience left behind" (Vargas Mena, 2014, p. 230). Vargas Mena problematizes methodological issues around oral sources, including for example, on how to do sampling, how to be prepared for an in-depth interview, and how to build an archive with these sources. Vargas Mena concludes emphasizing the transdisciplinary nature of environmental history. While it needs to take into account non-human dynamics (from plants, animals and others), for environmental history it is still "fundamental to approach civil society...in order to contribute to the urgent tasks of environmental protection and the social and political transformations that make history possible" (Vargas Mena, 2014, p. 257). Another author that reflects on the contributions of Latin American environmental history is Katherine Mora. She calls for going beyond the "declensionist" and tragic stories of the human/non-human relationship, while actively using historical approaches (especially from environmental history) in the construction of adaptative strategies for the present and the future (Mora Pacheco, 2018).

\section{Memory}

Memory has been the main concept that history has drawn upon to use participative methods. Memory is a complex concept and has many interpretations. For example, it is often asked where historiography ends and where memory starts (Traverso, 2007). As the historian and expert 
in cultural studies Mario Rufer conceptualizes it, memory is composed of public references to the past under a non-official or scholar context (Rufer, 2009). Another academic who has explored the concept of memory in depth is the historian Enzo Traverso. For him, memory can only be understood from the present, as it is composed of representations of the past at the individual or collective level, with historic continuity and filled with meaning and direction (Traverso, 2007). Historians do not have control over this type of knowledge, as explained by Gonzalo Pasamar, since they "share the public space with lots of other actors" (Pasamar Alzuria, 2003, p. 240). For that reason, memory (hand-in-hand with oral sources) was long deemed not valuable as an historic source. However, as explained earlier, by the turn of the century it was already widely accepted among historians of all latitudes that oral history had "freed us from the cul-de-sac question of veracity-falsehood" (Gallini, 2004) of testimonies. By then it was clear that oral sources responded to different questions from written ones. In addition, the interpretation of these sources also changed, because conventional history asks for what happened, whereas oral history asks for meaning (Portelli, 2009).

We argue that memory should be considered a necessary step of societal transformation processes within environmental activism, particularly constructed from a participative and decolonial approach. Engaging in the use of the concept of memory and decolonial participative approaches can also help in uncovering "the existence of diverse historical rationalities that fulfil legitimizing functions within conflicts" (Cusicanqui, 2008, p. 59). As Rivera Cusicanqui argues, in situations of inequality, the discipline of history can focus on unveiling the different interpretations of reality, not on determining the objective truth about what occurred in the past (Cusicanqui, 2008). In other words, to understand the meaning attached to the past "in terms of justice within a cause... making historic research a collective exercise of misalignment" (Cusicanqui, 2008) for the researcher and the communities that are involved in the research. Within the struggles faced by human and environmental rights defenders in the twenty-first century, unveiling the multiple, co-existent and sometimes contradicting memories among stakeholders has an impact in determining the route towards environmental justice. 
There can be multiple uses of the concept of memory for a decolonial and participative approach to environmental history. If the goal of the researcher is to commit to an engaged exercise of transformation, memory is a fundamental part of change. In a volume on historical memory in Africa, the anthropologist and historian of Africa oral history, Mamadou Diawara asserts that memory can be a "a rich and powerful tool for orientation in the present and for opening future perspectives on human action. Even on the most abstract level, the way in which we remember has consequences" (Diawara et al., 2010, p. 2). From a pedagogic studies perspective, Gabriela Ortiz says that memory:

can move in the quotidian life and be a powerful tool for fighting when brought to the present. Through the lived experience... memory is brought up to life by constituting transmitted experience that is commemorated in the collective, forming identities and the ways of being in life. (Ortiz Zambrano, 2019, p. 29)

Contrastingly, just as it is important to analyse what is remembered, one of the most important components of memory is forgetting, since "forgetting is the norm and remembering is the exception, even though constructed forgetfulness may exist" (Gallini et al., 2015, p. 54).

An illustration of the co-existence of multiple narratives of the past that determine identities is the 1927 massacre of banana workers by the United Fruit Company in Northern Colombia. Official reports limit the number killed to a maximum of 1,000 people, according to the then US ambassador (Bucheli, 2002). In popular memory, that number has been highly influenced by the publication of the Nobel laureate novel Hundred years of solitude (where it was suggested there were some 3,000 people killed) by Gabriel García Márquez (García Márquez, 1967). For current processes of labour and environmental inequalities in the area of the massacre, where bananas are still being planted, the popular memory of peasants, conservation workers and social movement gives higher priority to the collective memory than the archival sources (De la Rosa Solano, 2018). The remembering of this event has, for decades, fuelled the union movements in Colombia in the fight for proper work conditions. 
Another example we can offer here is drawn from fieldwork in the city of Coventry (UK) (undertaken by the first author, De la Rosa Solano), while researching the history of urban waterways. During the post-war period, the main river in the city was diverted underground, disconnecting it from the historic centre. While doing a social cartography exercise on a local festival, different inhabitants of the city informed De la Rosa Solano that they did not know about the existence of the river, a part of which still runs above surface not more than $200 \mathrm{~m}$ away from the festival. When asking environmental and local authorities about the problems around the river, the lack of citizen engagement in conservation and care was one of the main issues cited. In her research, De la Rosa Solano finds a connection between the lack of citizen engagement with the literal lack of visibility the river has in the city. In this case, one of the processes in the history of the river has been a constructed forgetting and the subsequent processes of remembering within artistic and environmental activities. ${ }^{7}$

Accessing individual and collective memory as a researcher can be done in multiple ways. Interviews, life stories, focal groups, social cartography, photo elicitation and other exercises are valuable in the quest for meaning about the past. Particularly, methods that push for interaction with the lived environment and exploration of the researched areas are fundamental in including the non-human in environmental history.

Finally, we would like to end this section by highlighting some reflections on the overall role of the researcher when using the concept of memory to engage in participative and decolonial methods. One useful piece of advice is given by Portelli, when he says that asking the interviewees for their life story, even if some of it is not directly related to the field of study, is of utmost importance. For him, oral history cannot be done, "unless your interest is focused on the person with whom you are talking" (Portelli, 2009, p. 29). The informant experiences are constituent of the ways remembering (and forgetting) is constructed. Silvia Rivera Cusicanqui makes two other notes. The first is to understand that there is cultural and linguistic untranslatability that is a natural part of different individuals with different backgrounds, like scholar

\footnotetext{
7 For more information on this research, see www.recoms.eu.
} 
researchers and communities. These need to be accepted and recognized. They can even bring opportunities for communities to build their narratives in their own terms and for their own purposes. Second, Rivera also reflects on the "negotiation" between the researcher and researched; this should be given in terms of "two subjects that reflect together around their experiences and about the vision each has of the other" (Cusicanqui, 2008, p. 60). These reflections are pointed towards the de-colonizing and construction of truly participative narratives of the past. There will still be limitations though, as previously discussed, depending mainly on each context where a participative and decolonial methodology is used.

\section{Conclusions}

This chapter has explored how participatory and decolonial methods of research can contribute to the practise of an inclusive and communicative environmental history that contributes to the cause of environmental justice. Discussed first, was how historical research has looked at inclusion, and then in turn, at participative approaches. The review of Latin American literature offered an introduction to an extensive body of scholarship that explores these topics, providing references for the one interested in taking this exploration further. From undertaking this review we argue that decoloniality and participation can be powerful allies of environmental history research. Namely, the decolonial approach helps reading the past through a critical lens that connects specific cases with larger phenomena, such as imperialism and capitalism, highlighting the spaces for change within them. Similarly, participation challenges historical research to go beyond inclusion and to place people's knowledge in the centre of scientific production. Environmental history brings together these elements to ask questions of the social sciences and humanities about non-human actors and to contextualize the discipline of history within the socio-environmental present day challenges.

The contributions of this chapter are three-fold. First we have studied the integration of social sciences methods for historical data collection in fieldwork; second, we have pointed out the relevance of people's knowledge for environmental history; and thirdly, we have highlighted the links 
between research practice of environmental history and environmental justice. This contribution was accompanied by a reflection on the fundamental task of including the non-human as part of that collective and individual narrative that forms the collective and individual identity. By way of illustration, the use of memory as a conceptual tool in applying this approach has also been explored. Likewise, by understanding the limits of participative and decolonial methods, the discussions in this chapter are intended to act as a foundation for further explorations on this way of doing environmental history. In this way, we can find spaces of convergence with social and environmental movements, similar to what is done in political ecology, but here, from an historical perspective.

This English language exploration of the evolution of participation in environmental history research in Latin America hopes to open the dialogue for exchanges between different traditions on methods in this field. More importantly, the particularities of the environmental history in Latin America, as they have been highlighted throughout this text, hope to inform research in other regions. Environmental history has already influenced policies in conservation in Latin America, and this is a clear route for more politically committed academic exercises in other latitudes. This type of research could be used for understanding the long-term temporality of social and ecological transformation and inform civil society of how inequities are shaped through time. Awareness of these issues can be created, and actively used, giving room to a politically committed academic practice from history. As many of the environmental historians from Latin America we have quoted, we strongly believe our field has a role to play in facing challenges of the twenty-first century. Among others, environmental history can be used to create awareness, push for inclusion, creating strategies for facing socio-environmental injustices, and have an impact on public policies.

Acknowledgements This research received funding from the European Union's Horizon 2020 research and innovation programme under the Marie Sklowdoska-Curie Grant Agreement No. 765389. 


\section{References}

Álvarez, L., \& Coolsaet, B. (2020). 'Decolonizing Environmental Justice Studies: A Latin American Perspective. Capitalism, Nature Socialism, 31(2), 50-69. https://doi.org/10.1080/10455752.2018.1558272

Apaza, I. R. L. (2019). Y qué con la historia oral? Un balance aproximado, perspectivas y cuestiones pendientes. Voces Educativas. Reflexiones desde la experiencia pedagógica.

Archila Neira, M. (2005). Voces subalternas e historia oral. Anuario Colombiano de Historia Social y de la Cultura, 32, 293-308. https://revistas.unal.edu.co/ index.php/achsc/article/view/8196. Accessed 15 December 2020.

Bergquist, C. (1989). En nombre de la historia: una crítica disciplinaria de la Historia doble de la costa de Orlando Fals Borda. Anuario Colombiano de Historia Social y de la Cultura, O(16-17), 205-229.

Bucheli, M. (2002). The united fruit company in Colombia: Labor, local elite and multinational enterprise 1900-1970. Standford University.

Burke, P. (1984). Historia popular o historia total. In R. Samuel (Ed.), Historia popular y teoría socialista. Crítica.

Carey, M. (2009). Latin american environmental history: Current trends, interdisciplinary insights, and future directions. Environmental History, 14(2), 221-252. https://doi.org/10.1093/envhis/14.2.221

Clare, P. (2009). Un balance de la historia ambiental latinoamericana. Revista Historia. https://www.revistas.una.ac.cr/index.php/historia/article/ view/3474/3331. Accessed 12 November 2020.

Curiel, O. (2014). Construyendo metodologías feministas desde el feminismo decolonial. In M. Franco (Ed.), Joirnadas de metodología e investigación feminista y aplicación en el ámbito de los derechos humanos (pp. 32-51). San Sebastián Donostia.

Cusicanqui, S. R. (2008). El potencial epistemológico y teórico de la historia oral: de la lógica instrumental a la descolonización de la historia. Teoria crítica dos Direitos Humanos no século XXI. Porto Alegre: EDIPUCRS, 154 175.

De la Rosa Solano, S. (2018). La maldita circuntancia del agua por todas partes. The evolution of the waterscape of the Cienaga Grande de Santa Marta between 1950-2010. Universiteit van Amsterdam. https://scripties.uba.uva. $\mathrm{nl} /$ search?id=658039. Accessed 16 December 2020.

De Souza Veras, J. J. (2012). A história oral e sua dimensão epistemológica. In XI Encontro Nacional de História Oral. Rio de Janeiro. 
Diawara, M., Lategan, B., \& Rüsen, J. (Eds.). (2010). Historical memory in Africa: Dealing with the past, reaching for the future in an intercultural context (Vol. 12). Berghahn.

Fernandez, R., Lauxmann, C. T., \& Facundo Trevignani, M. (2014). Emergencia del Sur Global. Perspectivas para el desarrollo de la periferia latinoamericana. Economia e Sociedade, 23(3), 611-643.

Gallini, S. (2004). Problemas de métodos en la historia ambiental de América Latina. Anuario AHES, 19, 147-171.

Gallini, S. (2009). Historia, ambiente, política: El camino de la historia ambiental en América Latina. Nómadas, 30, 92-102.

Gallini, S. (2020). Qué hay de histórico en la Historiografía ambiental en América Latina? Historia y Memoria, Especial, 179-233.

Gallini, S., De la Rosa Solano, S., \& Abello, R. (2015). Historia ambiental. In P. Ungar (Ed.), Hojas de ruta. Guías para el estudio socioecológico de la alta montaña en Colombia. Instituto de Investigación de Recursos Biológicos Alexander von Humboldt.

García Márquez, G. (1967). Cien Años de Soledad. Sudamericana.

Guha, R. (1982). Las voces de la historia y otros estudios subalternos. Crítica.

Hobsbawm, E. (2011). On history. Hachette.

Hughes, J. D. (2016). What is environmental history? Polity Press.

Kemmis, S., McTaggart, R., \& Nixon, R. (Eds.). (2014). The action research planner: Doing critical participatory action research. Springer.

Kindon, S., Pain, R., \& Kesby, M. (2007). Participatory action research approaches and methods: Connecting people. Routledge.

Kraikovski, A., \& Lajus, J. (2017). Living on the River over the Year: the significance of the Neva to Imperial Saint Petersbury. In M. Knoll, U. Lübken \& D. Scholl (Eds.), Rivers lost, rivers regained: Rethinking city-river relations (pp. 235-254). University of Pittsburgh Press. https://doi.org/10.2307/j.ctt 1 qnw8gv. 16

Lander, E. (2000). La colonialidad del saber: Eurocentrismo y ciencias sociales. Perspectivas latinoamericanas. CLACSO.

Lewin, K. (1946). Action research and minority problems. Journal of Social Issues, 2(4), 34-46.

Lugones, M. (2018). Hacia metodologías de la decolonialidad. In A. Escobar (Ed.), Prácticas otras de conocimiento(s). CLACSO.

McNeill, J. R. (2003). Observations on the nature and culture of environmental history. History and Theory, 42(4), 5-43. https://doi.org/10.1046/j. 1468-2303.2003.00255.x 
Mora Pacheco, K. (2018). Pensar el pasado para adaptarse al cambio climático. El aporte necesario de la historia ambiental latinoamericana. Letras Verdes, Revista Latinoamericana de Estudios Socioambientales, 24, 8-26.

Ortiz Zambrano, G. B. (2019). Cómo nos construimos desde la memoria? Revista Andina de Educación. Universidad Andina Simon Bolivar, 2(2), 2833. https://doi.org/10.32719/26312816.2019.2.2.4

Pasamar, G. (2003). Los historiadores y el "uso público" de la historia: Viejo problema y desafío reciente. Ayer, 49, 221-248.

Portelli, A. (2009). What makes oral history different. In L. Del Giudice (Ed.), Oral history, oral culture, and Italian Americans (pp. 21-30). Palgrave Macmillan. https://doi.org/10.1057/9780230101395_2

Puentes, J. P. (2015). Descolonización metodológica e interculturalidad. Reflexiones desde la investigación etnográfica. Revista Latinoamericana De Metodología De Las Ciencias Sociales RELMECS, 5(2), 6.

Rahman, A., \& Fals Borda, O. (1992). La situación actual y las perspectivas de la IAP en el mundo. In M. C. Salazar (Ed.), La investigación-acción participativa: inicios y desarrollos (pp. 205-233). Popular.

Rufer, M. (2009). La nación en escenas: memoria pública y usos del pasado en contextos poscoloniales. El Colegio de México.

Salazar, M. C. (1992). La investigación-acción participativa: inicios y desarrollos. Popular.

Sánchez-Calderón, V. (2017). A "slum river": The unequal urganization of Bogota (Colombia) and the transformation of the Tunjuelo River in the twentieth century. In M. Knoll, U. Lübken, \& D. Schott (Eds.), Rivers Lost (pp. 123-139). University of Pittsburgh Press.

Sánchez-Calderón, V., \& Blanc, J. (2019). La historia ambiental latinoamericana: Cambios y permanencias de un campo en crecimiento [Latin American environmental history: Change and continuity in a growing field]. Historia Crítica, 74, 3-18. https://doi.org/10.7440/histcrit74.2019.01

Suárez-Krabbe, J. (2011). En la realidad. Hacia metodologías de investigación descoloniales. Tabula Rasa, 14.

Tax, S. (1992). Antropología-acción. In M. C. Salazar (Ed.), La investigaciónacción participativa : inicios y desarrollos (pp. 27-36). Popular.

Thompson, E. P. (1963). The making of the English working class. Penguin.

Traverso, E. (2007). Historia y memoria. Notas sobre un debate. In M. Franco \& F. Levín (Eds.), Historia Reciente. Perspectivas y desafios oara un campo en construcción (pp. 67-96). Paidós.

Vargas Mena, E. (2014). Problemas metodológicos de la historia ambiental. Autocrítica de una experiencia de investigación con fuentes orales en el 
volcán Barva -Sacramento y Paso Llano-, Costa Rica. Revista de Historia, 70, 229-257.

Wallerstein, I. (1994). Open the social sciences: Report of the gulbenkian commission on the restructuring of the social sciences. Standford University Press. Available at: https://www.sup.org/books/title/?id=792. Accessed 16 December 2020.

Zamosc, L. (1992). Campesinos y sociólogos: Reflexiones sobre dos experiencias de investigación activa. In M. C. Salazar (Ed.), La investigación-acción participativa: inicios y desarrollos. Popular.

Open Access This chapter is licensed under the terms of the Creative Commons Attribution 4.0 International License (http://creativecommons.org/ licenses/by/4.0/), which permits use, sharing, adaptation, distribution and reproduction in any medium or format, as long as you give appropriate credit to the original author(s) and the source, provide a link to the Creative Commons license and indicate if changes were made.

The images or other third party material in this chapter are included in the chapter's Creative Commons license, unless indicated otherwise in a credit line to the material. If material is not included in the chapter's Creative Commons license and your intended use is not permitted by statutory regulation or exceeds the permitted use, you will need to obtain permission directly from the copyright holder. 